\title{
Plasma concentrations of cathelicidin and $\beta$-defensins and their correlations in patients with basal cell carcinoma
}

\author{
Marta Fijałkowska ${ }^{1}$, Marek Kowalski $^{2}$, Bogusław Antoszewski ${ }^{1}$ \\ ${ }^{1}$ Department of Plastic, Reconstructive and Aesthetic Surgery, Second Chair of Surgery, Medical University of Lodz, Lodz, Poland \\ ${ }^{2}$ Department of Immunology and Allergy, Medical University of Lodz, Lodz, Poland \\ Adv Dermatol Allergol 2022; XXXIX (1): 226-227 \\ DOI: https://doi.org/10.5114/ada.2022.113809
}

Non-melanoma skin cancers (NMSCs) are the most common neoplasms accounting for more than $95 \%$ of all of skin tumours and their incidence is dramatically increasing worldwide [1-3]. Skin cancers represent an important health problem and cause economic burden for the society and health services; it is said that NMSCs are about four times more costly than melanoma [4].

The pathogenesis of skin cancers is complex, however its exact mechanism of development has not been clearly described $[3,5]$. There are some reports that paid attention to changes in the expression profile of specific proteins linked to skin carcinogenesis [6-9]. In this group there are $\beta$-defensins and cathelicidin, which are the key participles of innate host defence against microorganisms [6, 10].

The aim of this paper is to measure the plasma concentrations of $\beta$-defensins and cathelicidin in patients with basal cell carcinoma (BCC) in comparison to healthy controls ( $\mathrm{HC})$ and to check the significance of their correlations.

A total of 70 patients admitted to our Department between March and May 2019 were enrolled in the present study. From that group, 20 patients were admitted due to skin tumours suspected of malignancy for its surgical removal and 50 patients suffered from other medical conditions, mainly aesthetic ones, operated on as 1-day procedure in our Clinic. All 20 patients with skin tumours had their operation done in local anaesthesia; excised skin neoplasm was sent to histopathological examination. After 2 weeks the results were obtained: 16 patients were diagnosed with BCC while 4 women had other benign lesions and were added to the healthy control group.

Prior to any surgical intervention, a $10 \mathrm{ml}$ blood sample was taken from every patient. Immediately after collecting, the blood was delivered to the Department of Immunology and Allergy where the sample was centrifuged to obtain plasma. Then it was frozen and stored in temperature minus $80^{\circ} \mathrm{C}$ until analysis. After collecting all of $70 \mathrm{sam}$ - ples, the plasma was refrozen and the concentrations of $\beta$-defensins (HBD-1, HBD-2, HBD-3) and cathelicidin were measured by Elisa Kit (EIAab Wuhan Science Co., Ltd ${ }^{\circledast}$ ).

All patients signed written consent forms prior to enrolment to the study. The project was approved by the ethics review board of the Medical University of Lodz (approval no. RNN/364/18/KE), and the study was conducted according to the Declaration of Helsinki principles. The data were statistically analysed using Statistica v13.1 (StatSoft Inc., Tulsa, OK, USA).

In the group of 70 patients, finally there were 16 with BCC and 54 HC. The group of BCC patients consisted of 9 women and 7 men, while the group of HC of 29 women and 25 men. The mean age of all patients was $64.1 \pm 12.0$ years (range: $44-89$ years). In the group of BCC patients, 10 of them had a nodular type of cancer, 2 - superficial type, 2 - ulcerative type, 1 - multifocal and 1 -in situ. The patients have had the cancer for 4 months to 3 years (mean time was 8 months). All of basal cell carcinomas were excised completely.

Cathelicidin was detected in almost every patient (except only one), HBD-2 in 62 cases, HBD-1 in 11 people, and HBD-3 only in one individual. The last parameter has been excluded from subsequent analyses. The mean concentration of cathelicidin in BCC patients was $1026.73 \mathrm{pg} / \mathrm{ml}$ and $795.84 \mathrm{pg} / \mathrm{ml}$ in HC. The level of cathelicidin was evidently higher in cancer patients than in healthy controls however it did not reach statistical significance. A similar situation was in relation to HBD-1 (Table 1). The mean concentration of HBD-2 was almost equal between the groups $-0.6 \mathrm{pg} / \mathrm{ml}$ in BCC patients and $0.7 \mathrm{pg} / \mathrm{ml}$ in controls (Table 1). Additionally it was revealed that the concentration of cathelicidin was higher in patients with a nodular type of BCC $(1189.11 \mathrm{pg} / \mathrm{ml})$ than in other types of skin cancer $(756.11 \mathrm{pg} / \mathrm{ml})$. A reverse situation was in relation to $\mathrm{HBD}-1$, the mean value in the nodular type was lower $(12.76 \mathrm{ng} / \mathrm{ml})$ than in the other types of BCC $(15.93 \mathrm{ng} / \mathrm{ml})$.

\footnotetext{
Address for correspondence: Marta Fijałkowska MD, PhD, Department of Plastic, Reconstructive and Aesthetic Surgery, University Hospital No. 1, 22 Kopcinskiego St, 90-153 Lodz, Poland, phone: +48 426776 742, e-mail: fijalkowska.m@wp.pl Received: 13.04.2020, accepted: 30.06.2020.
} 
Table 1. Comparison of measured parameters between the healthy group and the BCC group

\begin{tabular}{|c|c|c|c|c|c|c|c|c|c|c|c|}
\hline \multirow[t]{2}{*}{ Parameter } & \multicolumn{5}{|c|}{ Control group } & \multicolumn{5}{|c|}{ BCC group } & \multirow[t]{2}{*}{$P$-value } \\
\hline & $n$ & Mean & SD & Min. & Max. & $n$ & Mean & SD & Min. & Max. & \\
\hline Cathelicidin & 54 & 795.84 & 988.76 & 0.00 & 5684.87 & 16 & 1026.73 & 1575.46 & 168.09 & 6778.90 & 0.872 \\
\hline HBD 1 & 54 & 7.82 & 22.99 & 0.00 & 125.60 & 16 & 13.95 & 26.86 & 0.00 & 87.80 & 0.256 \\
\hline HBD 2 & 54 & 0.70 & 1.21 & 0.00 & 6.70 & 16 & 0.60 & 0.74 & 0.00 & 3.12 & 0.894 \\
\hline
\end{tabular}

$B C C$ - basal cell carcinoma, $H B D$ - human $\beta$-defensin, SD - standard deviation.

Table 2. Associations between measured parameters across gender and BCC presence

\begin{tabular}{|c|c|c|c|c|c|}
\hline \multirow[t]{2}{*}{ Parameter } & \multicolumn{2}{|c|}{ BCC group } & \multicolumn{2}{|c|}{ Control group } & \multirow[t]{2}{*}{$P$-value } \\
\hline & $R$ & $P$-value & $R$ & $P$-value & \\
\hline $\begin{array}{l}\text { Cathelicidin \& } \\
\text { HBD } 1\end{array}$ & 0.70 & 0.002 & 0.50 & $<0.001$ & 0.310 \\
\hline $\begin{array}{l}\text { Cathelicidin \& } \\
\text { HBD } 2\end{array}$ & 0.83 & $<0.001$ & 0.64 & $<0.001$ & 0.171 \\
\hline HBD 1 \& HBD 2 & 0.59 & 0.016 & 0.31 & 0.022 & 0.255 \\
\hline \multirow[t]{2}{*}{ Parameter } & \multicolumn{2}{|c|}{ Men } & \multicolumn{2}{|c|}{ Women } & $P$-value \\
\hline & $R$ & $P$-value & $R$ & $P$-value & \\
\hline $\begin{array}{l}\text { Cathelicidin \& } \\
\text { HBD } 1\end{array}$ & 0.47 & 0.007 & 0.60 & $<0.001$ & 0.469 \\
\hline $\begin{array}{l}\text { Cathelicidin \& } \\
\text { HBD } 2\end{array}$ & 0.66 & $<0.001$ & 0.70 & $<0.001$ & 0.768 \\
\hline HBD 1 \& HBD 2 & 0.46 & 0.008 & 0.35 & 0.033 & 0.601 \\
\hline
\end{tabular}

$B C C$ - basal cell carcinoma, HBD - human $\beta$-defensin.

Associations between particular values of proteins were checked (Table 2). The relations between cathelicidin and HBD-1, cathelicidin and HBD-2, and HBD-1 and HBD-2 were examined. In the BCC group, $R$ values varied from 0.59 to 0.83 and in the control group from 0.31 to $0.64(p<0.05)$. The $R$ values were notably higher for the BCC group than in the healthy control group. In men these $R$ values ranged from 0.46 to 0.66 and for women they ranged from 0.35 to $0.70(p<0.05)$.

Defensins and cathelicidin belong to antimicrobial peptides participating in defence against various microorganisms, that is why they are also called natural antibiotics [8]. There are reports paying attention to involvement of cathelicidin in skin cancer development. Kim et al. investigated whether the cathelicidin is involved in the carcinogenesis of malignant melanoma. The authors concluded that the protein promoted melanoma cell proliferation, migration and invasion in vitro [9]. In our study the concentration of cathelicidin was higher in BCC patients than in healthy controls. It did not reach statistical significance probably due to a small number of patients with basal cell carcinoma.

The concentration of cathelicidin is higher in patients with basal cell carcinoma. The correlations between the plasma concentration of cathelicidin, HDB-1 and HBD-2 seem to be higher in the group of BCC patients than in healthy controls. This indicates that defensins and cathelicidin may play a role in skin carcinogenesis and due to the complexity of this process, searching for a single protein which can be used as a marker of skin cancer is definitely not sufficient. This study is not without limitations. Our sample was a pilot sample with a quite small quantity of BCC patients so a potential bias cannot be excluded. Further research is needed and the tendency which occurred in our study should be confirmed with a larger cohort of patients with BCC.

\section{Conflict of interest}

The authors declare no conflict of interest.

\section{References}

1. Correia de Sá TR, Silva R, Lopes JM. Basal cell carcinoma of the skin (part 1): epidemiology, pathology and genetic syndromes. Future Oncol 2015; 11: 3011-21.

2. Stoddard M, Lyons A, Moy R. Skin cancer prevention: a review of current oral options complementary to sunscreens. J Drugs Dermatol 2018; 17: 1266-71.

3. Lesiak A, Czuwara J, Kamińska-Winciorek G, et al. Basal cell carcinoma. Diagnostic and therapeutic recommendations of Polish Dermatological Society. Dermatol Rev 2019; 106: 107-26.

4. Duarte AF, Sousa-Pinto B, Freitas A, et al. Skin cancer healthcare impact: a nation-wide assessment of an administrative database. Cancer Epidemiol 2018; 56: 154-60.

5. Ciążyńska M, Bednarski IA, Wódz K, et al. Proteins involved in cutaneous basal cell carcinoma development. Oncol Lett 2018; 16: 4064-72.

6. Nishi $\mathrm{Y}$, Isomoto H, Mukae $\mathrm{H}$, et al. Elevated serum betadefensins concentrations in patients with lung cancer. Anticancer Res 2004; 24: 4051-7.

7. Scola N, Gambichler T, Saklaoui H, et al. The expression of antimicrobial peptides is significantly altered in cutaneous squamous cell carcinoma and precursor lesions. Br I Dermatol 2012; 167: 591-7.

8. Suarez-Carmona M, Hubert P, Delvenne P, Herfs M. Defensins: "simple" antimicrobial peptides or broad-spectrum molecules? Cytokine Growth Factor Rev 2015; 26: 361-70.

9. Kim JE, Kim HJ, Choi JM, et al. The antimicrobial peptide human cationic antimicrobial protein-18/cathelicidin LL-37 as a putative growth factor for malignant melanoma. Br J Dermatol 2010; 163: 959-67.

10. Murata I, Hirayama T, Nakazato M, Kohno S. Concentrations of alpha- and beta-defensins in gastric juice of patients with various gastroduodenal diseases. World J Gastroenterol 2005; 11: 99-103. 